of completing it has fallen upon the deputy director, Mr. Denison Byles. The total average output from the works for the year was $310 \cdot 79$ million gallons per day. Of 22,000 routine samples examined bacteriologically, about 98 per cent were of first-class purity (absence of Bact. coli in 100 c.c.). Details are given of several researches carried out in the laboratories. In the Bacteriological Section, various methods for the isolation and identification of Bact. coli have been tested and compared. In the Biological Section, investigations into the algal flora of raw and stored waters have been continued. In the Chemical Section, a further account is given of the use of a new photo-electric turbidimeter. The chief analytical results for each month in the year of the several sources of supply are given in a series of tables.

\section{The Brotherton Collection}

The third annual report of the Brotherton Collection Committee, University of Leeds, states that a beginning has been made in the work of valuing the Collection, case by case, and of cataloguing the uncatalogued books (University of Leeds: The Brotherton Collection. Pp. 4. Leeds: The University, 1938). A scheme has been drawn up for the purchase of new books, which would be confined to certain authors and subjects wherein the Collection is already strong, so that relative completeness could be ob. tained. The very extensive collection of pamphlets on Sheffield has been re-arranged. Mr. J. A. Symington, first keeper of the Brotherton Collection, relinquished that office on July 31,1938 , and on the recommendation of the Brotherton Collection Committee, the Council of the University of Leeds appointed Dr. Richard Offor, the University Librarian, to be Keeper of the Collection from August 1 .

\section{The Earthquake of May 10, I939}

From instrumental reports from Fordham, Georgetown, St. Louis, Victoria, Honolulu, Manila, Pasadena, Philadelphia, Chicago and Burlington, the U.S. Coast and Geodetic Survey has determined the epicentre of the earthquake of May 10 at $7 \mathrm{~h} .44 \cdot 4 \mathrm{~m}$. G.C.T. to be provisionally lat. $51^{\circ} \mathrm{N}$., long. $179^{\circ} \mathrm{W}$. This is to the south of the Andreanof Islands, which form part of the Aleutian Islands, and is on the circumpacific ring of instability somewhat to the west of the epicentre of the great earthquake of November 10, 1938.

\section{Conference on Photography}

THE Manchester and District Branch of the Institute of Physics has arranged a Conference on Photography, to be held in the Physics Department, University of Manchester, on July 3 and 4, under the chairmanship of Dr. F. C. Toy. Among those taking part are Prof. N. F. Mott, Dr. J. C. M. Brentano, Dr. W. F. Berg, Dr. D. A. Spencer, Dr. S. O. Rawling, E. R. Davies, C. W. Bradley, Dr. J. G. Wilson, Dr. C. A. Adams and Dr. H. A. Bruck. The subjects to be discussed include the atomic physics of photography, colour photography, theories of developers, and applications of photography in research. Further particulars can be obtained from Dr. W. H. Taylor, Physics Department, College of Technology, Manchester, 1 .

\section{Marine Biological Association}

AT the annual general meeting of the Marine Biological Association of the United Kingdom, Dr. George Parker Bidder was elected president of the Association in succession to Lord Moyne, who had held office for the past nine years. Lord Moyne, Lord Mildmay of Flete, and Sir Reginald DormanSmith were added to the list of vice-presidents. Mr. H. C. Maurice, Lord Rothschild, Mr. J. R. Norman and Mr. Morley Neale were elected new members of council.

\section{Announcements}

Lieut.-Colonel J. H. M. Gremnly has agreed to continue as president of the Institute of Fuel for a further year, and will deliver his second presidential address on October 19. The Council of the Institute has awarded the Melchett Medal for 1939 to H. A. Humphrey, late consulting engineer to Imperial Chemical Industries, Ltd., for the outstanding work he has done in the development of fuel and appliances in connexion therewith.

Marc Tiffenead, professor of pharmacology and materia medica in the Faculty of Medicine, University of Paris, has been elected a member of the Section of Chemistry of the Paris Academy of Sciences, in succession to the late Prof. G. Urbain.

The German Chancellor has awarded the Goethe Medal for Arts and Science to Prof. Ernst Rudin, professor of psychiatry in the University of Munich, for his work on German racial hygiene.

THE annual meeting of subscribers and friends of the Rothamsted Experimental Station, Harpenden, will be held on June 28, when the principal speaker will be Sir E. Kaye Le Fleming, chairman of council of the British Medical Association.

Following the nineteenth annual general meeting of the British Non-Ferrous Metals Research Association on June 29, the Association's new laboratories in Euston Street, London, N.W.1, will be formally opened by the Right Hon. Oliver Stanley, president of the Board of Trade, and a memorial to Thomas Bolton will be unveiled.

THв Internationale Zeitschrift für Psychoanalyse und Imago, which was temporarily suspended, resumed publication in March 1939. The present address is 96 Gloucester Place, W.1, and the price 34 shillings.

According to the figures issued by the Metropolitan Life Insurance Company, the average duration of life for men in the United States in 1936 was 60.81 years, or 1 year and 3 months longer than in 1930 . 